\title{
ADMINISTRATIVE FINALITY AND FEDERAL EXPENDITURES
}

\section{HARVEY C. MANSFIELD †}

Administrative finality, we are learning over again, is of the essence of the power to govern in a society which places increasing reliance upon administration as a tool of government to achieve its collective ends. Limits there will be, since governing is not all that we expect of government; but within general limits effective action depends upon preserving an area of discretion which courts may not or will not invade. There must be limits too upon the downward extension of the separation of powers. The framers understood this well, and through most of the nineteenth century the federal courts understood it also. It is mainly within the present generation that the expansion of due process in the Ohio Valley Water Company case, ${ }^{1}$ Crowell v. Benson,, and their counterparts in other fields, has restricted administrative discretion as it previously had the legislative. The judicial technique that has been developed in these cases consists in erecting more barriers across the paths of administrative action than the courts have time or physical energy to defend, if they were called upon to do so in each case; and it is possible to tell which barriers are manned in any given case only after the final adjudication. Hostile encounters may be infrequent, but the administrative process is so concerned at each step with making a record that will withstand review that it loses the name of action.

A degree of finality in financial administration is equally vital to effective action. Finance is at least a housekeeping aspect of almost every administrative move, for the authority to spend public funds is an indispensable implement to the delegation of the power to govern. Constitutional safeguards of the appropriating power and of the Treasury, as of individual rights against regulation, must be protected without jeopardizing the vitality of government. In this field administrative discretion is checked less by the courts than by the Comptroller General, whose powers have developed since the establishment of his office in $1921^{3}$ at a more rapid rate than those of the courts. Though he is an administrative officer himself, the aggrandizement of his discretionary power carries with it pari passu a diminution of the freedom of action

$\uparrow$ Assistant Professor of Government, Yale University.

The substance of this article will appear in a forthcoming monograph on the subject.

1. Ohio Valley Water Co. v. Ben Avon Borough, 253 U. S. 287 (1920).

2. 285 U. S. 22 (1932).

3. The office was established by the Budget and Accounting Act. 42 Stat. 24 (1921), 31 U. S. C. $\$ 41$ (1934). For an early appraisal see Willougagy, Lrase Status and Functions of the General Accouritis Office (1927). 
of those other agencies whose principal concern is operation. It is proposed here to review the present status and recent trends of the Comptroller General's powers to interpret the statutes as they affect the expenditure of appropriations. The current controversy over administrative reorganization, centering on the Byrnes and Vinson bills pending in the present Congress, gives added point to such a review at this time.

I.

Under the prevailing procedure, appropriations, itemized in great detail and subject to a host of limitations general and special, are made directly to each department and agency for the support of its activities. ${ }^{4}$ The power of Congress to attach limitations to appropriations is as yet absolute, and no doctrine of unconstitutional conditions has been applied to curb such limitations. In the usual course obligations incurred in the administrative offices-by putting people on the payroll, by issuing travel orders, by signing contracts for supplies, services, public works, etc. are for the most part paid by the recently centralized Division of Disbursement in the Treasury, upon the certification of an officer of the agency originating the payment. ${ }^{5}$ The disbursing officers render monthly accounts current, listing these expenditures, together with the supporting vouchers, which, after examination in the originating department, are transmitted to the General Accounting Office. With some exceptions, claims and accounts by or against the United States are audited and settled there, i.e., the fidelity and legality of the payments is checked, and credit is disallowed in the accounts of disbursing officers for all payments not deemed to be supported by the proper evidence. Disallowances on the books of the General Accounting Office stand as personal debts of the disbursing officers, for which their sureties may be contingently liable. And since the Comptroller General's settlements, in the words of the statute, are "final and conclusive upon the executive branch of the government," $\theta$ executive officers may not appeal directly to the courts to review the Comptroller General's decisions.

4, For a description of the procedures and bookkeeping mechanics involved, see Financial Administration of the Federal Government, Report No. 5 to the Senate Select Committee to investigate the Executive Agencies of the Government, 75th Cong,, 1st Sess. (1937), by the Brookings Institution.

5. Prior to 1933 disbursing was done in each department and agency through its own officer. By Exec. Order No. 6166, $\$ 4$ (June 10, 1933), 5 U.S.C. $\S 132$, Note, under authority of the Economy Acts of 1932 and 1933, this function was consolidated in the Treasury. By Exec. Order No. 6728 (May 29, 1934), the Army and Navy and Panama Canal were exempted from the centralized scheme; and its application to the Post Office has been from time to time postponed.

6. 42 STAT. 24 (1921), 31 U. S. C. $\$ 44$ (1934), a power previously vested in the Comptroller of the Treasury by 15 STAT. 54 (1868). The Budget and Accounting Act also provided that the powers of the Comptroller General shall "be exercised without direction from any other officer." 
In this manner Congress initially confers administrative discretion and limits it, but through the device of settling accounts the Comptroller General determines in practice whether it has been validly exercised. In the process of settling he asserts the right to raise and decide for himself every question of law or fact involved in ascertaining the validity of a payment ${ }^{\top}-2$ right of review which results in the substitution of the reviewer's judgment for the administrator's on a far broader scale than the courts could undertake. It enables him to decide most questions of jurisdiction in his own favor, thus leaving it to his discretion to determine what evidence of the claim he will demand and whether general instructions can be laid down in advance, or whether he will insist upon passing upon cases individually before an obligation is incurred. His predilection for the latter procedure has a devastating effect upon operating efficiency.

This review differs from that of a court in that it does not depend on the complaint of a litigant but is automatically applied to every transaction, and, further, in that the Comptroller General, unlike a court, is himself an administrative officer directing an agency that currently employs nearly 5000 people and is charged with numerous other functions. Nevertheless, there are important resemblances to judicial review. First, the Comptroller General's tenure makes him independent of executive control. ${ }^{8}$ By the same token he is left indifferent to the pressure which no politically responsible officer can wholly escape, the pressure to do the substantive work for which administrative agencies are created.

7. Brief for the Comptroller General, p. 7, Mfiguel v. McCasl, 291 U. S. 442 (1934).

8. The act [supra note 6] gave the Comptroller General a term of fifteen years and made him removable only by joint resolution of Congress. The constitutionality of this provision has been much disputed. The argument in its favor is that it is necessary and proper for Congress to prohibit a removal, except on its own initiative, in order to protect the appropriating power and to give effect to the constitutional prohibition upon withdrawals from the Treasury except "in Consequence of Appropriations made by Law." Art. I, sec. 9. The argument against constitutionality is that removal is an incident of the appointing power, that though Congress may properly enact standards for removal appropriate to the character of the offee, it cannot compel the President to share the exercise of the power with another body. This was conceded by counsel in the Humphrey case [295 U.S. 602, at 609 (1935)] as to Senatorial participation, and would seem to apply a fortioni to removal by joint resolution, in which the President is deprived of any initiative. The argument that no restriction would be valid in view of the President's power to "talke care that the Laws be faithfully executed," upon which the Court relied in Aryers v. United States, 272 U. S. 52 (1926), is apparently no longer available since the Humphrey decision. See Cozwns, The Prestment's Rezrovar Power (1927) 64-5; Donovan and Irvine, The President's Power to Remove Members of Administrative Agencies, (1936) 21 Cosst. L Q. 215, 238. The question remains academic in the absence of an attempt to exercise the power, which political considerations seem to forbid. In fact there has been no question of the Comptroller General's complete independence. 
Second, although he is sometimes spoken of as an "agent of Congress," he is as independent of that body as any bureau chief, ${ }^{\circ}$ and not much less so than a court. Third, he acts upon a documentary record which it is incumbent upon others to supply. His decisions often disregard economy and efficiency and profess no criterion other than strict legality. They turn almost exclusively upon questions either of statutory construction or of the weight and sufficiency of evidence he will require. ${ }^{10}$

In some instances, to be sure, after the reasons for a proposal have been fully explained in advance, he gives his consent in the grudging formula, "This office is not required to object."11 This is particularly true in the case of agencies that deliberately choose to forego any contest of what might be deemed their jurisdictional rights for the sake of securing the Comptroller General's cooperation. More typical, however, are decisions that deny credit for the payment of mileage to an employe for travel in a personally-owned automobile, as authorized, because the car was registered in the employee's wife's name, not his own ;2 $^{12}$ or that deny credit for the transportation of the household effects of an employe on a change of duty stations, because the order authorizing the transfer was signed by the Assistant to the Secretary of the Interior instead of by the Secretary personally ;3 $^{\mathbf{3}}$ or that prevent the Farm Credit Administration from borrowing the services of Land Bank appraisers on leave without pay because of the dual compensation statute; although the annual amount to be paid did not exceed the limitations of that statute, and although the Farm Credit Administration was authorized to procure the services "notwithstanding the provisions of any other act."

The consequence is a vast, complex body of case-law governing every financial transaction. The detailed control thus imposed, though not the only, ${ }^{15}$ is certainly among the chief elements making for low morale, rigidity, and unwieldiness in the machinery of federal bureaucracy, It burdens administration with a terrific overhead cost in time, money, and personnel to maintain the necessary records and to thread the maze of decisions with which fiscal officers must be familiar. The problem

9. On the Comptroller General's relations with Congress, see President's CoMaittee on Administrative Management, Report with Spectal Studies (1937) 190. The principal difficulties are the want of any special machinery in Congress charged with the duty of receiving and acting upon his reports and recommendations, and the fact that having administrative powers of his own he prefers to use them rather than to report his findings to Congress.

10. The best evidence rule is applied.

11. 15 CoMp. GEN. 148 (1935).

12. 16 Comp. GeN. 23 (1936).

13. 15 Comp. GeN. 37, 171 (1935).

14. 15 CoMp. GEN. 184 (1935).

15. Personnel procedures are another headache. President's Commitree, op. cit. supra note 9, at 68-95. 
of devising financial procedures that will safeguard the Treasury and yet liberate the energies of executive agencies, for their substantive functions lies at the heart of any broad program of reorganization designed to improve governmental efficiency. Central to this problem is the need for a measure of discretion that will permit wider choice of means to particular ends than now usually exists. This need may be dealt with at two levels, legislative and administrative.

\section{II.}

Specific limitations that Congress has imposed, Congress may conceivably withdraw. These include such diverse matters as requirements that not more than a named amount of an appropriation be expended in the District of Columbia, ${ }^{16}$ that employees abroad must travel on American vessels where "available,"17 that only materials and supplies of American manufacture shall be acquired for public use or public works, ${ }^{18}$ that travel must be at the lowest first-class rate, ${ }^{10}$ that newspapers beyond $\$ 30$ worth a year, and law books, may not be bought without specific authority of law, ${ }^{20}$ that cotton price forecasts may not be published, ${ }^{21}$ and that no publicity expert or employee of the Pinkerton Detective Agency may be hired. ${ }^{22}$ Students of public finance are agreed that legislative appropriations are too minutely itemized and that so many detailed restrictions are self-defeating. Nevertheless, it is only rarely that specific limitations are repealed. ${ }^{23}$ They are usually enacted in the first instance as an expression of displeasure over the discovery of a particular practice; they often embody what is in most instances a desirable procedure.

16. This is found in virtually every regular appropriation act, though it is not 2 part of permanent legislation.

17. 49 Stat. 2015 (1936), 46 U. S. C. \$1241 (Supp. 1937).

18. 47 Stat. 1520 (1933), 41 U. S. C. $\S \S 10 \mathrm{a}, 10 \mathrm{~b}, 10 \mathrm{c}$. See 14 Co«r. Gerr. 381 (1934); id., at 601 (1935); 15 Cosrp. Gen. 763, 776 (1936); 16 Cosp. Gen. 1037. 1106 (1937).

19. 47 Stat. 1516 (1933), 5 U. S. C. \$73b (1934). Though no statute so requires, the Comptroller General holds also that it must be authorized in advance. 14 Con.op. GEN. 414 (1934).

20. REv. Stat. $\S 192,1779$ (1875), 5 U. S. C. $\$ 102$ (1934); 30 Stat. 316 (1893), 31 U. S. C. $\$ 678$ (1934).

21. This is a provision in the annual appropriation act for the Department of Agriculture, Office of the Secretary. It reputedly resulted from some senators burning their fingers in the cotton futures market.

22. 38 Stat. 212 (1913), 5 U. S. C. $\$ 54$ (1934); 27 Stat. 591 (1893), 5 U. S. C $\S 53$ (1934).

23. One recent instance was the notorious "Red Rider" attached in 1935 to the District of Columbia appropriation act [49 Srs. 341], which forbade the payment of salary to any school employee "teaching or advocating Communism." The Comptroller General required affidavits from every employee of the Board of Education every two weeks. 15 Coxr. GeN. 407 (1935). After much criticism the provision was striclien out in 1937. 
Their vice is inflexibility in particular cases, especially when their interpretation is left to the Comptroller General. ${ }^{24}$ Occasionally authority is delegated to the President or to department heads to issue regulations covering knotty technical subjects such as annual and sick leave ${ }^{25}$ or travel in personally owned automobiles, ${ }^{26}$ a trend that should be encouraged. It is unlikely, however, that except under emergency conditions Congress will soon hand over bodily a power which its members individually find it advantageous to exploit.

Congress has at times recognized the difficulties attending administration under the Comptroller General's supervision by exempting some agencies or transactions from his jurisdiction, or by making the findings of some other officials binding upon him. Such recognition comes most readily when the Comptroller General steps on the toes of a powerfully organized interest. The need for secrecy in national defense and for dispatch and flexibility in business and lending operations have also proved convincing. Thus, the amounts of veterans' adjusted compensation payments as fixed by the Administrator of Veteran's Affairs, ${ }^{27}$ and of commodity benefits and soil conservation payments as fixed by the Secretary of Agriculture, ${ }^{28}$ are not reviewable. Internal revenue and customs assessments, in the absence of fraud or mathematical error, may not be reviewed except in the courts. ${ }^{29}$ Expenditures by the State Department from its secret fund, ${ }^{30}$ by the Navy for foreign intelligence, ${ }^{31}$ by the Board of Governors of the Federal Reserve System, ${ }^{32}$ by the President for the Executive Offices, by the Supreme Court, and by congressional

24. A prime example that has occasioned as much difficulty as any single requirement is the one calling for the letting of contracts, after advertising, to the lowest responsible bidder "when the public exigencies do not require . . . immediate delivery . . or performance." REv. Stat. \$3709 (1875), 41 U. S. C. \$ 5 (1934). No one disputes the rule; every department has had occasion to dispute the rulings.

25. 49 Stat. 1162 (1936), 5 U. S. C. $\$ \S 30 f, 30 k$ (Supp. 1937).

26. 46 Stat. 1103 (1931), 47 Stat. 1516 (1933), 5 U. S. C. $\$ 73 a$ (1934). Sec Standardized Government Travel- Regulations.

27. 46 STAT. 1016 (1930), 38 U. S. C. $\$ 620$ (1934); 48 Stat. 9 (1933), 38 U. S. C. $\S 705$ (1934). The Comptroller General in 1934 spoke of these as "rare cases where the Congress has by specific language made the finding or decision of some other official conclusive." Brief for Comptroller General, op. cit. supra note.7, at 15. For a list of 22 recent instances see ANNuAl Report of the Acting CoMrptroller General (1937) 60-63.

28. 49 Stat. 767 (1935), 7 U. S. C. \$610(e) (Supp. 1937); 49 Stat. 1151 (1936), 16 U. S. C. $\$ 590 \mathrm{n}$ (Supp. 1937).

29. 44 StaT. 113 (1926), 26 U. S. C. $\$ 1690$ (1934); 49 STAт. 1753 (1936), 7 U. S. C. $\$ 651$ (Supp. 1937) (refunds of processing taxes); as to customs assessments see WILLOUGEBY, op. cit. supra note 3 , at c. 7 .

30. Rev. Stat. \& 291 (1875), 31 U. S. C. \$ 107 (1934).

31. 39 Stat. 557 (1916), 31 U. S. C. $\$ 108$ (1934).

32. 48 Stat. 167 (1933), 12 U. S. C. $\$ 244$ (1934). 
committees, ${ }^{33}$ are similarly not reviewable. The Navy Department enjoys a special authority of ancient standing to make payments contrary to existing law, ${ }^{34}$ subject to later legislative relief. Finally, some government corporations, the more important of which are the Reconstruction Finance Corporation, ${ }^{35}$ the Federal Deposit Insurance Corporation, ${ }^{36}$ the Farm Credit and Home Loan groups of banks, ${ }^{37}$ and the Inland Waterways Corporation, ${ }^{38}$ are wholly outside the Comptroller General's jurisdiction. He audits but does not settle the accounts of the Fleet Corporation $^{39}$ (now the Maritime Commission) and of the Tennessee Valley Authority. ${ }^{40}$ Taken together, these are substantial exceptions in favor of administrative discretion in the operating agencies, and their number is increasing steadily. They serve to emphasize the need of a greater measure of freedom in the remaining establishments.

III.

At the administrative level, the Comptroller General's settlements are, as has been said, by law "final and conclusive upon the executive branch."

33. The language of the appropriation acts, rather than permanent legislation, malies the certificates of the President, Chief Justice, and committee chairmen conclusive.

34. Rev. Stat. $\$ 285$ (1875), 31 U. S. C. $\$ 106$ (1934).

35. 47 Stat. 6 (1932), 15 U. S. C. $\$ 604$ (1934). See generally, Peesidzhits Comar. op. cit. supra note 9, at 299-308; McDiarmid, Government Corforations ord Federal Funds (1937) 31 Axs. PoL. Scr. Rev. 1094; MfcGuire, Gotermment by Corporations (1928) 14 VA. Law Rev. 186; ANwUal Refort of tae Acting Colstmolien General (1937) 16-32; Beck, Our Wonderlandd of Butenucract (1928) 128; for Congressional views see 79 CoNg. REc 1546 ff., 3261 (1935).

36. 48 StAT. 168 (1933), 12 U. S. C. $\S 264(k)$ (1934).

37. 39 Star. 361 (1916), 12 U. S. C. $\$ 657$ (1934) (Land Banles); 48 Srar. 344 (1934), 12 U. S. C. $\$ 1020$ (1934) (Farm Mortgage Corporation); 42 Srat. 1454 (1923), 12 U. S. C. $\$ 1023$ (1934) (Intermediate Credit Banks). These are all audited and controlled by the Farm Credit Administration, which is subject to the Comptroller General's jurisdiction. 48 Stat. 129 (1933), 12 U. S. C. $\$ 1463(j)$ (1934) (Home Owner's Loan Corporation); 47 STAт. 738 (1932), 12 U. S. C. $\$ 1440$ (1934) (Home Loan Banks) ; 49 STAт. 298 (1935), 12 U. S. C. $\$ 1725$ (c) (5) (Supp. 1937) (Federal Savings and Loan Insurance Corporation). By Exec. Order No. 6549, Jan. 3, 1934, all emergency agencies, including corporations, created after March 3, 1933 and not specially provided for by law were directed to render accounts to the Comptroller General. The F.D.I.C. and H.O.L.C. have never come to terms with him.

38. 43 Stat. $360-2$ (1924), 49 U. S. C. $\$ \S 151,155,156$ (1934). The corporation's books are audited by private accountants.

39. 42 Stat. 444 (1922), 49 STAT. 1988 (1936), 46 U. S. C. $\$ 1117$ (Supp. 1937). The Comptroller General devoted a section of every annual report to his perennial controversy with this agency. But see Awnual Report of tBE Actric Cousptrolues GENeral (1937) 69-78.

40. 48 Stat. 63 (1933), 16 U. S. C. 831 (h) (1934). The Comptroller General's relations with the Authority have not yet been adequately dealt with in print. $C f$. Hearings before House Military Affairs Committee on Tennessec Valley Authority, 74th Cong., 1st Sess. (1935) 557 ff.; Annual Report, Tenuesser Valley Autuoutty (1936) 71-2. 
Does this mean that the Comptroller General's constructions of law, upon which the settlements depend, are also binding rules for administrative action? This is a crucial question as to all activities not specifically exempted by law. The answer is generally yes. But this is not because of any clear statutory mandate to him to interpret the laws, for there is none. It is rather because the administrative sanctions placed at his disposal are so compelling that if he chooses to invoke them in behalf of his views of the meaning of a statute, there are few who can say him nay. He can, in Professor Corwin's phrase, decide what he cannot prove. It is these sanctions rather than any statutory enlargement of his jurisdiction that make his decisions matter more than did those of the Comptroller of the Treasury before him. By the same token, however, the reach of his administrative compulsions marks out the boundaries of the area within which his decisions are law. Once safely outside the ambit of these controls a departmental chief may afford to disregard his rulings. In view of the rigidity of the system the importance of any avenue of escape is magnified. Without reviewing all the Comptroller General's powers, which include the countersignature of all warrants, ${ }^{41}$ the prescription of departmental accounting forms and procedures, ${ }^{42}$ access in

41. 28 Stat. 209 (1894), 31 U. S. C. $\$ 76$ (1934). All withdrawals, advances, deposits, and transfers of funds are legally. accomplished by warrants originating in the Treasury, which serve as posting media for bookkeeping. Potentially, counter-signature is the most drastic of controlling powers, and its importance has greatly increased in the past two years. Two factors have limited its availability as a weapon. The Budget and Accounting Act did not repeal the provisions of $\S 12$ of the Duckery Act of 1894 [31 U. S. C. $\$ 78$ (1934)] which, in vesting the immediate exercise of the power in the office of Comptroller of the Treasury created by that act, lodged a reviewing authority in the Secretary of the Treasury and the President. The Comptroller General has persistently sought to secure such a repeal, thus far without success. ANNUAL REPORT of the Cosaptroller General (1926) 10 ; id. (1927) 4 ; id. (1931) 2 ; id. (1937) 12. Further, a comprehensive and reliable set of central accounts capable of reflecting currently the status of all appropriations is needed as a basis for action. Efforts to develop these in the General Accounting Office are in progress but have not been brought to fruition. Id. (1937) 1-4. The threat to withhold further advances was used to bring the Tennessee Valley Authority to heel early in 1936.

42. 42 Stat. 25 (1921), 31 U. S. C. $\$ 49$ (1934). This power had been vested in the Comptroller of the Treasury by $\S 5$ of the Dockery Act, but had been administratively construed as limited to the forms of accounts to be rendered to the Auditors by accountable officers. Annual Report, Comp. of tae Treasury (1914) 9. The Comptroller General has interpreted it to cover all accounts kept within the departments as well. The use of approved forms can be compelled through the refusal of the Public Printer to execute orders for forms not bearing the Comptroller General's O.K., but he complains that he has no means of compelling departments to maintain the accounting systems he prescribes. Annual Report of the Acting Comp. General (1937) 5 . The question of jurisdiction is posed by $\S 10$ of the Dockery Act [5 U.S. C. $\S 255$ (1934)] which directs the Division of Bookkeeping and Warrants "under the direction of the Secretary of the Treasury" to keep "all accounts of receipts and expenditures of public money." 
the course of investigation to all departmental records, ${ }^{43}$ and reports to Congress, it will suffice for purposes of illustration to consider his primary function of settling accounts.

Certificates of settlement from the General Accounting Office are statements of the accounts of individuals with the United States. They include both the claims of private individuals against appropriated moneys not paid by the departments and the accounts of disbursing officers. As to the latter they show the total of advances, with adjustments for transfers, the credits allowed for sums deemed properly paid, and the balances due under each appropriation; the last includes unexpended balances and payments for which credit has been disallowed. A demand for refund of the disallowances accompanies the settlement, ${ }^{44}$ and if a clearance is not obtained, a certificate of the debt ascertained is forwarded to the Attorney General for suit against the disbursing officer and his surety. At this point the Comptroller General's control of the proceedings stops. The disbursing officer is not entitled to any other statement of his account, but the Comptroller General has no automatic means of collecting the debt he has stated.

Disallowances may be cleared, with the aid of the department concerned, by a recoupment from the payee ${ }^{45}$ or from the certifying officer who signed the voucher and who is now apparently legally liable in the disbursing officer's place. ${ }^{46}$ This occurs chiefly where the payee is a government employee and where the mistake is departmental or the amount involved is not worth prolonged controversy. Probably less than $10 \%$ of the amounts disallowed are recovered in this way. The major proportion are cleared by further explanations resting on additional evidence or on different theories of the cases, or by applying the payments to different appropriations. Another substantial group are relieved by subsequent acts of Congress, ${ }^{17}$ which may go further and affirmatively authorize similar payments in the future. In a residuum of cases recovery waits on the action of the Attorney General and the courts.

The jurisdictional boundary between the Comptroller General and the Attorney General has never been satisfactorily defined. A department

43. 42 StAт. 26 (1921), 31 U. S. C. $\$ \S 53,54$ (1934).

44. The Comptroller General maintains a debt card index of all lnown debtors to enable him to make offsets against future payments to them.

45. Under the Stoppage Act [49 Stat. 1374 (1936), 5 U. S. C. \$46b (Supp. 1937)] department heads may now withhold pay as a means of requiring their employces to refund disallowances.

46. ExEC OrDER No. $6166, \S 4$ (1933). The validity of the transfer of "the funetion of accountability" has not been tested in the courts. See 13 Covsp. GeN. 326 (1934); cf. Isbrandtsen-Moller Co. v. United States, 300 U. S. 139 (1937); Swayne \& Hoyt v. United States, 300 U. S. 297 (1937).

47. Recent examples: 49 Stat. 2074, 2080, 2135, 2142, 2219, 2236 (1935-6); Private No. 6, Miarch 10, 1937; Private No. 264, Aug. 10, 1937. 
head may consult the former with respect to any contemplated payment, ${ }^{48}$ and the latter on any question of law arising in the administration of his department. ${ }^{49}$ Sharp words have been used by both officers in protesting against alleged encroachments, ${ }^{50}$ but on the basis of the business done the Comptroller General has had the better of the argument. He receives annually several thousand requests for advance decisions on the legality of payments, the Attorney General only a handful. Indeed, an examination of the submissions made to the Comptroller General reveals questions asked and answered that go far beyond the legality of payments. ${ }^{51} \mathrm{He}$ is not restricted by the doctrine occasionally observed by the courts, of limiting his decision to the issues necessarily presented. It is apparent that the Comptroller General is consulted more often, not because his views are more palatable-for the opinions of the Attorneys General are consistently more favorable to departmental views - but because department heads are anxious to know what he will do on settlement; and their questions are broad because they feel they might as well learn the worst at once. The fact that the Attorney General is still consulted at all indicates that department heads may at times look beyond the Comptroller General's settlements. This is confirmed by figures on the disposition of cases referred by the General Accounting Office for suit, which show the extent of the Attorney General's discretionary review in prosecuting. ${ }^{52} \mathrm{He}$ will not prosecute a disbursing officer for a payment made in reliance upon his advice. In some instances suit may be nominally instituted to preserve the Government's right against the surety from being barred by limitation. ${ }^{53} \mathrm{He}$ also takes into account

48. 28 STAT. 207 (1894), 31 U. S. C. $\$ 74$ (1934).

49. Rev. StAT. $\$ 356$ (1875), 5 U. S. C. $\$ 304$ (1934).

50. 2 CoMr. GeN. 784 (1923); 5 id. 688 (1925); 14 id. 648 (1935); 33 Ops. Atr'y GEN. 383 (1922) ; 34 id. 5, 48 (1923) ; 34 id. 83, 217, 311, 346 (1924); 36 id. 289 (1930); 37 id. 95, 219 (1933) ; 37 id. 409, 437, 446, 461, 477, 493, 534, 562 (1934); cf. LANGELUTtig, The Departarent of Justice (1927) c. 13.

51. E.g., 13 CoMrp. GEN. 22 (1933) (organization of Bureau of Internal Revenue); 15 CoMp. Gen. 352, 619 (1936) (low-cost housing rentals); 15 Cossp. Gen. 400 (1935) (milk marketing agreements).

52. Of 957 cases for a total of $\$ 7,600,000$ referred between July 1,1925 and Sept. $1,1937,221$ for $\$ 363,706$ were collected in full; 106 uncollectible judgments for $\$ 820,000$ were also obtained. Judgments went for the debtors in 45 cases involving $\$ 362,000$; Congress relieved 85 for $\$ 178,000$; the Comptroller General withdrew 110 for $\$ 1,122,000$. In all the remainder, that is, over one third of the total number for two-thirds of the total amount, either no action was taken or the Attorney General reached compromisc settlements. Letter of the Acting Comptroller General to Senator Byrnes, A-87280, November 17, 1937.

53. Until recently it was the practice of the Department of Justice to withhold the institution of suit at the request of the department concerned, pending departmental efforts to get relief legislation or otherwise to secure a clearance, upon the filing by the surety of a waiver of the five-year limitation on its liability imposed by 25 STAT. 387 (1888), 6 U.S.C. \&5. But in United States v. U. S. Fidelity \& Guaranty Co, 
the grounds of disallowance, the substantial equities involved, and the fact that the bond often does not cover the disallowances.

This attitude is not wholly a reflection of the Attorney General's desire to protect executive discretion against the Comptroller General, though that element doubtless enters into consideration. It is based also upon the Comptroller General's none too successful experience in the courts. The courts have shown no special deference toward his views as those of "a tribunal informed by experience," though the law accords to his statements of disbursing officers' accounts a prima facie evidence of indebtedness. But since executive officers are foreclosed by the terms of the statute from challenging the correctness of settlements in the courts, direct review at the instance of the government can be had only in a suit against a disbursing officer or payee to vindicate a settlement and collect the debt stated. Such suits are rare. Ordinarily they will not be brought unless the Attorney General and Comptroller General are in agreement as to the latter's jurisdiction. ${ }^{\text {at }}$ If they disagree, it is safer for the Attorney General not to bring suit than to trust that he will lose it. One test case, however, was brought and lost. In Heller v. United States the court declined to permit recovery of payments, made in good faith and on orders of a superior, by a War Department disbursing officer in France. Acknowledging that if the officer knew the payments were illegal or knew a fact that should suggest their impropriety, he would pay at his peril even though believing his act was for the best interests of the government, the court. refused to apply the absolute liability contended for. Quoting a case ${ }^{56}$ antedating the Budget and Accounting Act it said:

"It hardiy seems that the financial operations of the government could go on if, at the peril of. refunding the money, every subor-

25 F. (2d) 500 (D. Md. 1928) and United States v. Geise, 56 F. (2d) 583 (C.C.A., 2nd, 1932), the statutory limitation was held to be a jurisdictional bar, not subject to waiver. Consequently, if the Department of Justice desires to preserve the surety's liability while trying to protect the disbursing officer, it must at least commence suit within that period. Since it has not been the Comptroller General's practice to issue a certificate of settlement until toward the close of the four-year term of a disbursing officer's bond, an actual trial on the merits of a disallowance is not lilsely to be had until several years after the transaction in question was made.

54. Miaryland Casualty Co. v. United States, 37 F. (2d) 318 (C. C. A Ath, 1930); Fidelity \& Deposit Co. v. United States, 55 F. (2d) 100 (C.C. A. 4th, 1932); Heidt v. United States, 56 F. (2d) 559 (C. C. A. 5th, 1932), cert. denicd, 287 U. S. 601 (1932).

55. 1 F. Supp. 1 (D.MAd. 1932). The decision whether or not to appeal, of course, rests with the Attorney General; this is a source of continuing dissatisfaction to the Comptroller General.

56. United States v. Warfield, 170 Fed. 43, 45 (C. C. A. 4th, 1909). The nineteenth century cases, which are reviewed in Smythe v. United States, 188 U. S. 156 (1903), with one exception sustained an absolute liability, but they dealt with questions of physical custody rather than of the finality of the Comptroller's decisions. 
dinate was required to exercise his own judgment over whether every apparently legal claim which his superior directed him to pay, was legal or not."

In view of this result the Attorney General is free to pick and choose among the cases referred to him.

IV.

Private parties are not legally foreclosed by an adverse decision of the Comptroller General, and where the consequence of court action is to establish a statutory interpretation contrary to his, the scope of departmental discretion may be thus indirectly enlarged. Two sorts of remedy are available: the prosecution of a claim in the Court of Claims, and proceedings by mandamus or mandatory injunction in the district courts. In the Court of Claims the Comptroller General's rulings may be challenged either by reclaiming a refund of an item he has disallowed, or by claiming an amount withheld by a department at his behest. The Court may take a different view of the law. Nor is it confined to the record before him, for trials are de novo. Moreover the Court is not restricted as he is to claims against available appropriations. The result of the Court's exercise of these powers has been that in the past dozen years it has allowed nearly 400 claims for a total of approximately $\$ 4,300,000$ which had been rejected by the Comptroller General. ${ }^{67}$ And he, for his part, does not recognize the judgments of the Court of Claims as precedents binding upon him beyond the individual cases. ${ }^{68} \mathrm{He}$ follows them only so far as he agrees with them. Within limits this stand is well taken. The Court has been known to reverse itself and to be reversed by the Supreme Court to accord with the Comptroller General's views, ${ }^{00}$ whereas the latter's mistakes in favor of litigants are irremediable. ${ }^{60}$ In a few classes of cases, however, this attitude has been carried to the point of bootless obstinacy. Dozens of claimants, each on precisely

57. Letter of the Acting Comptroller General, loc. cit. supra note 52. The General Accounting Office settles annually over 100,000 claims, exclusive of transportation accounts.

58. 14 Comp. GeN. 648 (1935). This was also the view of the Comptrollers of the Treasury, though they were less disposed to act on it in practice. 3 Dec. First Comp., xxoxix (1882). Hotcheiss, Judictal Work of the Comptroller of the Treasury (1911) c. 2.

59. Shook v. United States, 61 Ct. Cl. 816 (1926); Nord v. United States, 78 Ct. Cl. 795 (1934); Tall v. United States, 79 Ct. Cl. 251 (1934); United States v. Rider, 261 U. S. 363 (1923), rev'g 57 Ct. Cl. 323 (1922); United States v. Ferris, 265 U. S. 165 (1924), rev'g 57 Ct. Cl. 566 (1922); United States v. Morrow, 266 U. S. 531 (1925), rev'g 58 Ct. Cl. 20 (1923); United States v. Noce, 268 U. S. 613 (1925), rev'g $58 \mathrm{Ct}$. Cl. 688 (1923); United States v. Lenson, 278 U. S. 60 (1928), rev'g 63 Ct. Cl. 420 (1927).

60. Mullett v. United States, 21 Ct. Cl. 485 (1886). 
similar facts, have been taxed with the cost and effort of court proceedings to get what it was plain the Court would grant without argument, to the benefit of no one except attorneys specializing in claims cases. ${ }^{01}$ In the most publicized of these instances legislation vas ultimately obtained which expanded the discretion of the department head, the Secretary of the Navy. It is probable that the occasions for acute controversy in this regard have diminished with the retirement of the former Comptroller General.

Since 1925 relief against the Comptroller General by mandamus and injunction has also been obtainable. Earlier effurts to use these remedies against Treasury officers had been unavailing, the Supreme Court in 1890 in United States ex rel. Lisle v. Lynch ${ }^{62}$ refusing to direct the Comptroller to settle a claim in a particular way. The immediate occasion for the change in view was an unnecessarily harsh and arbitrary attempt of the Comptroller General to offset alleged overpayments against the salaries of army and navy officers. In spite of his strenuous protests, on jurisdictional grounds as well as on the merits, relief was given in the form of mandamus or mandatory injunction to compel the disbursing officer to pay and to restrain the Comptroller General from interfering. ${ }^{63}$ On similar facts about 150 decrees were granted to officers who applied for them before Congress enacted relief legislation. Although

61. In McCabe v. United States, 84 Ct. Cl. 291 (1936), the Comptroller General was severely criticized for not following the Court's decisions in Bullard v. United States, $66 \mathrm{Ct} . \mathrm{Cl} .264$ (1928) and a score of similar cases. Penn Bridge Co. v. United States, $59 \mathrm{Ct}$ Cl. 892 (1924) led to a like situation.

62. 137 U. S. 280 ; cf. Brashear v. Mlason, 6 How. 92 (U. S. 1848); United States ex rel. Goodrich v. Guthrie, 17 How. 284 (U. S. 1854) ; Decatur v. Paulding, 14 Pet. 497 (U. S. 1840).

63. McCarl v. Wylly, 5 F. (2d) 964 (C. C. A. 1st, 1925); McCarl v. Cor, 8 F. (2d) 669 (App. D. C. 1925). The Attorney General, not displeased with the outcone, declined to certify that he thought the lower court was in error in the latter case, and certiorari was denied, 270 U. S. 652 (1926). See also AicCarl v. Pence, 18 F. (2d) 809 (App. D. C. 1927) ; Baker v. MfcCarl, 24 F. (2d) 897 (1928) ; McCarl 7. Emerson, Loud \& Orcutt, 38 F. (2d) 943 (App. D. C. 1930). Contra: Barber v. Hetfield, 4 F. (2d) 245 (C. C. A. 9th, 1925) ; Annual Report of the Costptzolien Genterar (1925) 9 ; id. (1926) at 7. These decisions were rested upon Smith v. Taclscon, 246 U.S. 389 (1917), in which the Supreme Court affirmed a mandamus decree compalling the Auditor of the Panama Canal to pay the full salary of the District Judge of the Canal Zone, against which the Auditor, with the approval of the Comptroller of the Trusury; had insisted upon offsetting deductions for living quarters previously furnished free, and for excessive vacations. Chief Justice White's opinion was a stinging rebulie to the Auditor. The decision was, however, no real precedent for the later cases. The Auditor was an executive officer of the Panama Canal, not an auditor of the Treasury; and District Courts in the United States outside the District of Columbia have no original jurisdiction to grant mandamus. Kendall v. Stokes, 12 Pet. 524 (U.S. 1833). The mandamus suits above were stopped by relief legislation which the Acting Comptroller General somewhat disingenuously referred to as putting "an end to such technical avoidance of financial responsibility." Letter, supro note 52 , at 8. 
the result was to sustain the departmental view in the particular situation, these proceedings provided no general enlargement of the scope of departmental discretion. All that was obtained was a ruling that the Comptroller General could not further diminish that discretion, and entrench his own, by using as offsets against salaries disallowances not yet reduced to judgments. Indeed the remedy proved a two-edged sword; for while a department might welcome a court order to pay what it was quite willing to pay, it had no control over the plaintiffs, and might, if the remedy were freely used, be confronted with an order to pay that it did not relish. When contractors and other private creditors began to resort to the process, however, the Attorney General rallied to the defense of the united interests of the departments and the Comptroller General, and the suits were generally unsuccessful. ${ }^{64}$

In Miguel v. McCarl, ${ }^{65}$ the only case to reach the Supreme Court in which the Attorney General and the Comptroller General were avowedly at odds, a most anomalous legal result was reached. A War Department disbursing officer, entertaining doubt whether a Philippine Scout was to be regarded as part of the enlisted personnel of the Army so as to be entitled to a retirement allowance, requested an advance decision from the Comptroller General, who replied that the payment was "not authorized even by the remotest implication of the laws." The petitioner brought suit for mandatory injunction in the Supreme Court of the District of Columbia to compel the Chief of Finance of the War Department to direct his subordinate to pay, and to restrain the Comptroller General from interfering. The court granted the decree as to both officers, but was unanimously reversed as to both by the Court of Appeals. ${ }^{68}$ In the argument upon certiorari the Attorney General and the Judge Advocate General supported the petitioner, leaving the Comptroller General to defend the decision below. While both sides argued the merits of the rather tangled maze of statutes affecting retired pay and Philippine Scouts, the main burden of the War Department's argument was that the Secretary's determination of the status of an enlisted man was final

64. United States ex rel. Carroll Electric Co. v. McCarl, 8 F. (2d) 910 (App. D. C. 1925); United States ex rel. Skinner \& Eddy Corp. v. McCarl, 275 U. S. 1 (1927); United States ex rel. Margulies \& Sons v. McCarl, 10 F. (2d) 1012 (App. D. C. 1926), cert. den., 273 U. S. 696 (1926); MrcCarl v. Walters, 38 F. (2d) 942 (App. D. C. 1930) ; McCarl v. Leland, 42 F. (2d) 346 (App. D. C. 1930), cert. denied, 282 U. S. 839 (1930) ; McCarl v. Rogers, 48 F. (2d) 1023 (App. D. C. 1931) ; Richmond, F. \& P. R. Co. v. McCarl, 62 F. (2d) 203 (App. D. C. 1932), cert. den., 288 U. S. 615 (1933) ; McCarl v. Hoeppel, 68 F. (2d) 440 (App. D. C. 1933); Lowry v. McCarl, 79 F. (2d) 144 (App. D. C., 1935), cert. den., 296 U. S. 637 (1935) ; Farrington v. Pink (App. D. C., June 28, 1937), cert. den., 58 Sup. Ct. 143 (1937).

65. 291 U. S. 442 (1934). The Attorney General permitted the Comptroller General to file his own brief, since the two disagreed and the latter was a named respondent.

66. 66 F. (2d) 564 (App. D. C., 1933). The decision below is unreported. 
and not open to review by the Comptroller General. Contrariwise, the latter's chief contention was that his decision upon a question of payment was conclusive upon the War Department, which could not thus be compelled to pay what it had no authority to pay; and that petitioner's remedy, if any, was in the Court of Claims. The Supreme Court, despite the disagreement below, found the petitioner's right to the allowance so plain that the duty to pay was ministerial, and reversed the Court of Appeals as to the Chief of Finance. "It seems unnecessary to add," Mr. Justice Sutherland added, "that this duty cannot be affected by a contrary decision of the Comptroller General." As to that officer, he continued, however : ${ }^{\text {B }}$

"The view . . that a manuatory injunction will lie to compel
a return of that voucher... and to enjoin the Comptroller General
from any interference... has not, in the light of the case now
made, met with the concurrence of a majority of this court .
But it is not to be supposed that, upon having his attention called
to our decision, the Comptroller General will care to retain pos-
session of the voucher or that he will interfere in any way with its
payment."

Unless the Miguel case is taken by implication to overrule the Lynth case, the only logically sound conclusion appears to be that while the Comptroller General cannot be compelled to settle a claim in a particular way, he can be enjoined from interfering with its payment by a department if the Supreme Court later agrees that the right of the payee under the law is clear. Which leaves the question of finality pretty much in the air. And the only psychologically sound conclusion appears to be that the courts are readier to direct administrative action now than they were in 1890. Neither the Comptroller General nor department heads will find their problems of financial administration clarified on that account.

On the whole, taking into account the fact that probably less than a tenth of one per cent of the transactions passed upon in the General Accounting Office reaches the courts in any form, and that when one does it is in the main at the instance of private litigants, it must be concluded that the attitude of the courts has not been a major factor in determining the scope of administrative discretion in expenditures. The Attorney General's role, by virtue of his control of suits to collect disallowances, is more important but still minor. An apparent paradox results that can be explained only by the weight of intangible factors. The departments obey the Comptroller General and submit to his expanding assertions of jurisdiction. They respect his power of disallowance to the extent of maintaining expensive staffs to guide their actions in con-

67. 291 U. S. 442 , at 454,456 (1934). 
formity with his decisions. They flood his office with requests for advance decisions to avoid disallowances. They do this despite the fact that most disallowances are not collected and that judicial process cannot be counted upon to aid collection. Here as in other fields the ultimate sanctions of behavior are not judicial. Administrative officers have jobs to get done and cannot afford much time or energy for jurisdictional controversy. It is significant that the attitude most consistently jealous of the Comptroller General's encroachments has been displayed by the service departments, War and Navy, which feel that pressure least and have not always chosen meritorious cases to contest. ${ }^{68}$ The time factor alone has been a major element in many cases, especially in recent years. Some agencies have been compliant, too, because of confidence in their ability to get legislative backing when needed. Furthermore, no administrator cares to be put on the defensive as to his financial record. The case against him may be bad, but in the public eye it is a prima facie case. In consequence, the Comptroller General's decisions are taken as the rules of the game, to be beaten perhaps if opportunity affords, but otherwise to be followed. The scope of departmental discretion in expenditures therefore turns first, upon the specific legislation applicable to each agency, and second, upon the personal and institutional attitudes of the Comptroller General and his staff.

As to the first, there can be little informed doubt that the general legislation is too restrictive. The current trend is definitely toward liberalization, which operates very unevenly. Although complete exemption is seldom justifiable, there are too many cases, especially among the older agencies, where adequate freedom of action has been unobtainable. A revision of some basic features of the existing system in the direction of administrative autonomy seems likely to produce fairer results and fewer hazards than piecemeal tinkering, which may result in dispensing with legitimate safeguards. As to the second, it may be urged with some plausibility that many of the difficulties experienced since 1921 are attributable to the personality of the former Comiptroller General and need not recur with a different type of appointee. It may indeed be presumed that no one who came to the office with first hand experience of operating problems would fail to act with more self-restraint. But an enormous weight of precedents in decision and office practice has accumulated in support of recent policies, and these are unlikely to be materially modified in the absence of further legislation. Moreover, much of the trouble inheres in the system, which invites the attitudes that have prevailed.

68. The independent commissions, on the other hand, whose appropriations are almost wholly devoted to salaries of a stable staff, small traveling allowances, and office supplies, have as a group been most disposed to cooperation. Agriculture, with a winning way in Congress and an able Finance Officer in control, has had least trouble among the departments. 
No officer completely divorced from executive responsibility, who is in practice the arbiter of his own jurisdiction, and whose approval of the details of every transaction must be secured by the submission of a formal record, can be expected to satisfy himself without at the same time unduly hampering the operating agencies. Nothing short of basic statutory changes will greatly alter these underlying considerations.

\section{V.}

The reorganization bills now pending in Congress ${ }^{\mathrm{CO}}$ as a result of the Report of the President's Committee on Administrative Management, and of committee hearings on the subject, contain two provisions directly designed to meet the demand for a larger measure of administrative discretion in expenditures. They do not go so far as the Report urged, nor do they deal with all the sources of present difficulty. Whether, taken in conjunction with other provisions of the bills, they would provide an adequate solution, can only be ascertained by trial.

The first change would vest the power of settlement in an executive officer appointed by the President and serving without definite term. In the Senate bill this is accomplished by transferring the power to the Director of the Budget and abolishing the General Accounting Office as such. The House bill leaves the power with a Comptroller General, who remains at the head of the General Accounting Office, but the term and tenure provisions of the Budget and Accounting Act are repealed. Under both bills, however, settlements would be made only after an audit under the direction of an Auditor General who would enjoy the same term and protection against removal now accorded the Comptroller General. And under both bills there are provisions ensuring reports to Congress of any settlements made contrary to the views of the Auditor General. A more expeditious and probably more discriminating audit is envisaged by the requirement that it be decentralized and "conducted as nearly as practicable in the vicinity of disbursing offices."

The administrative advantages of such an arrangement are twofold. The first is in attitude. An officer so placed could be expected to look rather to the positive than the negative purposes of appropriations and to choose among possible alternative interpretations of law the one most favorable to the efficient accomplishment of operating tasks. Particularly if the responsibility were combined with Budget work, this should shift

69. S.3331, Title III, reported by Senator Byrnes from the Select Committee on Government Organization (S. Rep. No. 1236); H. R. 8276, reported by Mir. Vinson (H. Rep. No. 1606) 75th Cong., 1st Sess. Senator Byrd also introduced S. 2530 to give effect to the recommendations of the Brookings Institution that difficulties the Comptroller General has experienced be cured by extending his powers. No hearings have been held on this bill; but see his Individaal Views, published as Part 2 of S. Rep. 1235, 75th Cong., 3d Sess. Earlier drafts of the Senate bill are S.2700, S.2969 and S.2970. 
the emphasis from technical regularity to economical performance. It should facilitate also the use of general instructions formulated in regulations in place of some of the case-law adjudication that now fills the volumes of the Comptroller General's decisions. The other advantage lies in permitting the development of a regularized administrative process for handling disallowances so as to distinguish technical infractions from substantial irregularities. It is a manifest weakness of the present system that in the eyes of the Comptroller General all disallowances, whatever their grounds, look alike. His effort to apply to disbursing officers a liability for refund irrespective of fault is the basis of most of the trouble in enforcing settlements. Neither Congress, the courts, nor the executive will be cooperative in giving effect to so unyielding a rule. An executive officer making settlements after an independent audit could draw some distinctions upon a review of the auditor's exceptions, referring appropriate cases to the Attorney General, invoking the Stoppage $\mathrm{Act}^{70}$ against the salaries of those who had been merely careless, and including in the Budget a recommendation for relief where that seemed warranted. By this last means, ultimate congressional control would be assured.

The second change is designed to protect delegations of authority to departmental officials against encroachments by the Comptroller General or the Budget Director. It permits the Atiorney General to decide questions of jurisdiction (but not of the merits of particular cases) between the heads of operating establishments and the central financial authority. In the words of the Senate bill, ${ }^{71}$

"The Attorney General . . . shall render an opinion with respect to the jurisdiction of the Director of the Bureau of the Budget [to whom the functions of the General Accounting Office are transferred] in connection with the settlement of any public account, or

70. 49 Stat. 1374 (1936), 5 U. S. C. $\$ 46 \mathrm{~b}$ (Supp. 1937). Though designed to enable department heads to protect disbursing officers as against recalcitrant payees who were also government employees, it could readily be used to enforce an administrative review of disallowances.

71. $\S 301(b)$. The language of $\S 4$ of the Vinson bill is to the same effect. The Vinson bill specifically defines the power of settling accounts to "include the power to determine the availability of appropriations, but such functions . . . shall not include the power to revise the action of other officers of the Government under statutes vesting in and imposing upon them power to make findings of fact or decisions in matters arising in their departments . . ." Ibid. Further, after authorizing the proposed Auditor General to audit all accounts, to investigate, and to report, it states that he "shall exercise no functions other than those vested . . . by this title or by any subsequent law, and nothing contained in this title shall be construed as authorizing the Auditor General to revise the settlements . . . made by the General Accounting Office . . ." $\$ 6$. 
any claim or demand against the United States, upon request therefor, within sixty days after receipt of notice of such settlement, by the said Director or the head of the executive department, independent establishment, or independent agency concerned, and any such opinion . . . shall be final and conclusive upon the said Director and all other officers and agencies of the Government."

This would put a stop to the continual aggrandizement of jurisdiction flowing from the power of settlement and would eliminate many of the present grounds of complaint.

Other provisions of the bills raise broader issues than administrative discretion, or deal with aspects of it outside the scope of this paper. ${ }^{72}$ The bills are also significant for what they do not attempt. They do not challenge the underlying premise that a detailed audit of all transactions is required, i.e., that a central authority must check every official financial act of every government employee. The time may well come when this, too, will seem an impossible or unnecessarily expensive burden of central machinery on the operating agencies, and sampling procedures may be substituted. The first need, however, is a measure of discretion in expenditures more nearly commensurate with the scale of the responsibilities now imposed on national administration. It is ton soon to speak of the outcome of the present reorganization moves. The history of previous efforts does not encourage optimism. Whether they succeed or whiether less ambitious steps must suffice for the present, the trend of events is in the direction of liberating administration to meet the needs of expanding social organization.

72. A Congressional Joint Committee on Public Accounts is included in the Byrnes bill to provide machinery for a closer legislative scrutiny of public accounts. In the latest draft of the bill it is also empowered to appoint the proposed Auditor General.

Both bilis put the power to prescribe accounting forms and procedures in executive hands, either in the Treasury or the Budget Bureau. The latter alternative was urged by President Hoover, acting under the reorganization provisions of the Economy Act of 1932, 47 Stat. 413. H. Doc. No. 493, 72d Cong., 2d Sess. (1932) 69-70. 